\title{
EVALUATION OF CERES-MAIZE MODEL FOR HYBRID MAIZE (Zea mays L.) PRODUCTION
}

\author{
Amied Ali, Bashrat Ali
}

\begin{abstract}
The trial was conducted at Agronomic Research farm, University of Sargodha during spring growing season, 2015, to calibrate and evaluate CERES-Maize model for simulating the impact of different sowing time on maize crop. The experiment was laid out in split plot design having three replications, keeping planting dates (25 ${ }^{\text {th }}$ Feb, $6^{\text {th }}$ Mar and $14^{\text {th }}$ Mar) in main plots and hybrids i.e. (DK-9108, DK-6525 and DK-6142) in the sub plots. The Calibration of CSM-CERES-Maize model showed the best possible closeness between simulated and observed days to flowering and physiological maturity, leaf area index (LAI), Total dry matter (TDM), and grain yield with \% error of $4.0,-1.5,0.41,0.07,0.14$ and $0.3 \%$, respectively, when maize hybrid $\mathrm{H} 1$ (DK- 6142) was sown at firstsowing date (25th Feb). DSSAT,CERES- Maize model predicted the phenological traits like anthesis and maturity phase. Number of days to anthesis and maturity simulated by model were lesser to the observed values, where as, simulated grain yield was higher as compared to observed data for all the three cultivars. Model calculated the close similarity between experimental and computer-generated values for leaf area index.
\end{abstract}

Keywords-Calibration, Evaluation, Hybrids, Phenology, Simulation

\section{INTRODUCTION}

Maize being a versatile crop can be grown over a range of agro climatic zones i.e. in tropical, subtropical and temperate climate throughout the world. Climate change extend the potential growing season allowing early planting of crops in spring. Yield decreases due to elevation of temperature and shorter crop duration also yield decrease due to moisture stress in increasing temperature. So to get maximum yield of maize determination of proper sowing time and selection of appropriate variety is very important.

High temperatures accelerate plant development, reducing the length of growth periods necessary for optimum development of plant and grain. Yield losses due to terminal heat stress could be avoided through simply changing planting dates and maize varietal types [1] (Harrison,2011).Performance of spring planted maize can be improved by reducing the damaging effects of low temperature upon early growth and of high temperature on pollination and grain filling by early plantation of short duration varieties that are tolerant to low or high temperature [2] (Afzaletal ,.2012).Accurate selection of planting time does not disturb production budget, but definitely will affect yield and consequently, farmer's profit

[3] (Forsthoferet al,. 2006). Each hybrid has an optimum sowing time; more the deviation from this optimum (early or late sowing), the more will be the yield loss [4], [5] (Sarvari and Futo, 2000: Berzsenyi and Lap.2001). Crop modeling has become a vital tool for supporting scientific research, crop improvement and strategy analysis [6], [7],

[8] (Fischer et al,2000; Hammer et al, 2002;Hansen. 2002). 
In latest decades, crop modeling has developed as state-of the art research tool and an important constituent of agriculture related decision support systems [9] (Stephens and Middleton. 2002). Crop models offer a means of estimating potential sources for variations in yield over time within a given site [10] (Keating and McCown.2001). Modeling techniques have also proved supportive in decision making procedures Cropping system model (CSM), computer based software, is an important research tool to examine the effects of more complex and ultimate management decision in crop production.The CSM-CERES

-Maize has been recognized as a useful mean to examine the possible impacts of climate change on crop production [11], [12], [13] (Keating et al,. 2003; Wu,.2006; Wang et al., 2009).Keeping requirements and importance of crop modeling in view, the present study was carried out to determine proper planting time of maize hybrids by using CSM-CERES-Maize model under agro climatic situations of Sargodha, Pakistan. The CSM-CERES-Maize models offer an integrated platform to continue developing and testing model improvement and accurately simulate leaf area, biomass and grain yield.

\section{MATERIALS AND METHOD}

The trial was carried out at experimental area of Research Farm, University College of Agriculture, University of Sargodha with randomized complete block design (RCBD) in split plot arrangement keeping sowing dates (25 $^{\text {th }}$ Feb, $6^{\text {th }}$ Mar and $14^{\text {th }}$ Mar) in main plots and maize hybrids

i.e. (DK-6142, DK-6525 and DK-9108) hybrids of Monsanto in sub plots. The experiment was comprised of 3 replications. The net-plot size was $2.25 \times 6 \mathrm{~m}$ maintaining $\mathrm{R}$ $\mathrm{x} R$ distance of $75 \mathrm{~cm}$ and $\mathrm{P} \times \mathrm{P}$ distance of 20 $\mathrm{cm}$. The crop was sown manually in ridges. The crop was sown with seed rate of $25 \mathrm{kgha}^{-1}$. All other management practices were kept normal. The study was conducted with the objectives to assess the phenology, growth and yield component of maize by the Application of CSMCERES-Maize model for planting dates evaluation and yield forecasting for maize (Zea may L.) hybrids. Additional information regarding experiment and soil is given in table 1.

TABLE 1. SUMMARY OF FIELD ATTRIBUTES SOIL AND CROP MANAGEMENT

\begin{tabular}{llll}
\hline Location & Latitude & Longitude Altitude & soil \\
series Climatic & zone $\quad \mathrm{N}^{0} \mathrm{E}^{0}(\mathrm{~m})$ & USDA \\
Classification & & \\
& & \\
\hline Sargodha $32.04^{0}$ & $\begin{array}{l}72.67^{0} \\
\text { Bhalwal } \\
\end{array}$ & Semi- \\
Arid (Fine-silty, mixed hyperthermic & \\
\hline
\end{tabular}

A. Crop growth modeling 
CERES-Maize is a process-orientedmodel, which has the potential to predict phenology, growth and yield under various environmental conditions. Daily climatic observations (max. temperature, min. temperature, precipitation), site information (latitude, longitude, altitude, soil physical, chemical and morphological properties), crop management information regarding tillage, plant population, seed rate, sowing depth, application of irrigation, fertilizers and a set of genetic coefficients' that describes hybrids in terms of development and kernel biomass are required to run the model. Calibration as well as evaluation of model was done with the field data collected from the trial during 2014, with best treatment for calibration and for genetic coefficient calculation but the evaluation of the model was assessed by using the independent set of data recorded. Precision of the model was assessed by comparing the model-simulated data with the observed data [14] (Hoogenboom et al,2010).

\section{B. Model Calibration}

In calibration, different model parameters were adjusted according to climaticconditions of Sargodha, Pakistan. Genetic coefficients of local hybrids were also determined for model calibration. The model was run and calibrated by using collected data against the best performing treatments in the field.

\section{Model Evaluation}

The model-simulated data were compared with recorded data during the year 2014 for evaluation of model's accuracy. Furthermore, actual and simulated values were compared. Simulation performance was checked by computing different statistic indices.

\section{RESULTS AND DISCUSSION}

\section{A. Model calibration}

It is a processing of adjusting some model parameters to the local conditions. It is necessary to get genetic coefficient for new cultivars in modeling studies. So genetic coefficient for under study cultivars were estimated in calibration process. The model was calibrated with data collected during the crop season against treatments, performed best in field. Cultivar coefficients were determined successfully using standard procedure and are presented in table 1-3. Model successfully simulated phenology, growth, grain yield during calibration process for all maize hybrids. Calibration results showed that model

predicted days to flowering and days to maturity accurately. 
There was only 2, 1 and 3 days difference between observed and simulated days to maturity in case of maize hybrid DK-6142, DK6525 and DK-9108 respectively. Maximum leaf area index was simulated with error $\%$ of 0.7 , 2.9, 1.5, and -1.9 for maize hybrids DK-6142, DK- 6525 and DK-9108 respectively. There was a good agreement between observed and simulated grain yield for hybrids DK-6142, DK-6525 and DK-9108 with error of 3.0

1.6 and $3.1 \%$, respectively. The calibration of crop biomass was also well simulated for hybrids DK-6142, DK-6525 and DK-9108 with error $\%$ of $3.22,9.79$, and $6.42 \%$ respectively. Plant Height was also well simulated for hybrids DK-6142, DK-6525 and DK-9108 with error \% of $2.17,9.25$ and 3.03 , respectively (Table 4).

\section{B. Time course simulation of crop biomass}

Time course simulation of crop biomass is presented in figures (1-9). Best simulated results with good agreement with observed results for leaf area index (LAI) were of $25^{\text {th }}$ Feb sowing. During the time course simulation of LAI, model over-estimated the LAI until the flowering stage and under -estimated after that for hybrid H1 (DK-6142). In case of hybrid H2 (DK-6525) model over-estimated the LAI during whole growth period and become equal to observed LAI at maturity. In case of hybrid H3 (DK-9108) model over-estimated the LAI during whole growth period. These results are in line with those of [15] Verma et al. (2012). They calculated time course LAI that was in good agreement with observed data for sole cropping system of maize. However, under semi-arid conditions model over- estimated the biomass during vegetative stage and under estimated during the reproductive stage.

Table 1. Genetic coefficient of DK-6142

\begin{tabular}{|c|c|c|}
\hline Genetic coefficient & Values & Unit \\
\hline $\begin{array}{l}\text { est_days_endjuv } \\
\text { to_init }\end{array}$ & 35 & 0C \\
\hline $\begin{array}{l}\text { tt_emerg_to_endj } \\
\text { uv }\end{array}$ & 280 & 0C \\
\hline $\begin{array}{l}\text { tt_flower_to_matu } \\
\text { rit } \\
\text { y }\end{array}$ & 925 & 0 C \\
\hline $\begin{array}{l}\text { head_grain_no_m } \\
\text { ax }\end{array}$ & 1900 & $\begin{array}{c}\text { Mg/grai } \\
\text { n/ day }\end{array}$ \\
\hline grain_gth_rate & 18 & $\begin{array}{c}\text { Mg/grai } \\
\text { n/ day }\end{array}$ \\
\hline tt_flag_to_flower & 0.0 & 0 C \\
\hline
\end{tabular}




\begin{tabular}{|c|c|c|}
\hline $\begin{array}{c}\text { tt_flower_to_start_ } \\
\text { g rain }\end{array}$ & 245 & 0 C \\
\hline $\begin{array}{l}\text { tt_maturity_to_ri } \\
\text { pe }\end{array}$ & 10 & 0C \\
\hline x_stem_wt & 0.0 & g/stem \\
\hline y_height & 65 & mm \\
\hline
\end{tabular}

Table 2. Genetic coefficient of DK-6525

\begin{tabular}{|c|c|c|}
\hline Genetic coefficient & Values & Unit \\
\hline $\begin{array}{l}\text { est_days_endjuv_to_ } \\
\text { init }\end{array}$ & 15 & ${ }^{0} \mathrm{C}$ \\
\hline tt_emerg_to_endjuv & 290 & ${ }^{0} \mathrm{C}$ \\
\hline $\begin{array}{ll} & \text { tt_flower_to_maturit } \\
y & \end{array}$ & 805 & ${ }^{0} \mathrm{C}$ \\
\hline head_grain_no_max & 890 & $\begin{array}{l}\text { Mg/grain } \\
\text { day }\end{array}$ \\
\hline grain_gth_rate & 9.30 & $\begin{array}{l}\text { Mg/grain } \\
\text { day }\end{array}$ \\
\hline tt_flag_to_flower & 40 & ${ }^{0} \mathrm{C}$ \\
\hline $\begin{array}{l}\text { tt_flower_to_start_g } \\
\text { rain }\end{array}$ & 40 & ${ }^{0} \mathbf{C}$ \\
\hline tt_maturity_to_ripe & $\mathbf{0 . 0}$ & ${ }^{0} \mathrm{C}$ \\
\hline x_stem_wt & $\begin{array}{l}0.0 \\
60\end{array}$ & g/stem \\
\hline y_height & $\begin{array}{l}0.0 \\
1970\end{array}$ & $\mathbf{m m}$ \\
\hline
\end{tabular}

\begin{tabular}{|c|c|c|}
\hline $\mathbf{y}$ & & \\
\hline head_grain_no_max & 300 & $\begin{array}{l}\text { Mg/grain/ } \\
\text { day }\end{array}$ \\
\hline grain_gth_rate & 85 & $\begin{array}{l}\text { Mg/grain/ } \\
\text { day }\end{array}$ \\
\hline tt_flag_to_flower & 48 & ${ }^{\circ} \mathrm{C}$ \\
\hline $\begin{array}{l}\text { tt_flower_to_start_g } \\
\text { rain }\end{array}$ & 120 & ${ }^{0} \mathrm{C}$ \\
\hline tt_maturity_to_ripe & 1.0 & ${ }^{0} \mathrm{C}$ \\
\hline x_stem_wt & $\begin{array}{l}0.0 \\
60.5\end{array}$ & g/stem \\
\hline y_height & $\begin{array}{l}0.0 \\
1890\end{array}$ & $\mathbf{m m}$ \\
\hline
\end{tabular}

Table 4. Summary of observed and simulated results during model calibration with data recorded against $25^{\text {th }}$ Feb sowing.

\section{Variable Unit Variety Observed Simulated Error (\%)

\begin{tabular}{llll}
\hline & & DK-6142 & 76
\end{tabular}

Flowering days

DK-6525

79

\begin{tabular}{lrrr} 
DK-9108 & 76 & 79 & -3.7 \\
\hline & DK-6142 & 125
\end{tabular}

$127-1.5$

Maturity days DK-6525

$122-0.8$

DK-9108

119

2.5

DK-6142

$4.18 \quad 0.4$

Maximum LAI DK-6525

4.07 $-2.9$

DK-9108

3.99 
Table 3. Genetic coefficient of

DK-9108

\begin{tabular}{|c|c|c|}
\hline Genetic coefficient & Values & Unit \\
\hline est_days_endjuv_to_ \\
init & 48 & ${ }^{0} \mathrm{C}$ \\
\hline tt_emerg_to_endjuv & 290 & ${ }^{\mathbf{0}} \mathrm{C}$ \\
\hline tt_flower_to_maturit & $\mathbf{7 2 0}$ & ${ }^{\mathbf{0}} \mathrm{C}$ \\
\hline
\end{tabular}

DK-6142

7306

7279

0.3

Grain yield $\mathrm{kg} \mathrm{ha}^{-1}$ DK-6525

6942

69.07 0.5

DK-9108

5651

5418

4.3

DK-6142

0.06

Total

biomass

14671

ha-1

0.2
16189

14709 
0.

C. Model evaluation

Precision of the model simulation and performance of genetic coefficient were gauged by running the model with data collected during the crop growth period under two sowing dates i.e. $6^{\text {th }}$ Mar and $14^{\text {th }}$ March. Evaluation results for two sowing dates are presented in table 5.

D. Days to flowering.

With the delay in sowing of the crop, number of days to flowering was reduced in all hybrids. This was an indication that maize development and phenology is influenced by variation in sowing time. At $6^{\text {th }}$ March sowing, days to flowering were closely predicted by the model with the average error $(-6.0 \%)$. With the delay in sowing date, greater difference was detected between simulated and observed days to flowering. Average error (8.0\%) for number of days to flowering was recorded in $14^{\text {th }}$ Mar sowing. Model predicted days to flowering were less than the observed days for all hybrids i.e. DK-6142, DK-6525 and DK-9108 sown on $6^{\text {th }}$ March and $14^{\text {th }}$ Mar. These results for the performance of model are in line with those [16] Chen et al. (2010) in which predicted days to flowering were less than observed days.

\section{E. Days to maturity.}

A very good prediction for number of days to maturity was given by the model. In both sowing dates, simulated and observed days to maturity was in close agreement with each other. Average error, $-2.0 \%$ and $1 \%$ were recorded in $6^{\text {th }}$ March and $14^{\text {th }}$ Mar sowing respectively. Model predicted days to maturity were less than the observed days for all hybrids i.e. Dk-6142, DK6525 and DK-9108 sown on $6^{\text {th }}$ March. In case of $14^{\text {th }}$ Mar sowing model over- estimated in case of sowing model under-estimated LAI in maize hybrids DK- 6142 and DK-6525 while overestimated in maize hybrids DK-9108. [17] Lizaso et al. (2010) simulated leaf area index with coefficient of determination 0.65 .

DK-6142 hybrid and under-estimated in case of DK-6525 and DK-9108. These results proved the model ability to predict maize phenology with good accuracy when it is sown under different sowing dates. [16] Chen et al. (2010) reported the similar results while studying the interaction among sowing dates, hybrids and plant densities.

$F$. Leaf area index.

Evaluation of leaf area index with CERESMaize model with data collected on two different sowing dates and three maize hybrids showed that the best prediction was for $6^{\text {th }}$ March sowing with average error of $0.00 \%$. This value for $14^{\text {th }} \mathrm{Mar}$ sowing was $0.00 \%$. Overall there was an underestimated of LAI in maize hybrids, DK-6525 and DK-9108, and over-estimated in case of DK-6142 at $6^{\text {th }}$ March sowing. Maximum simulation error \% (1\%) was given by Dk-6142 in case of $6^{\text {th }}$ sowing. In case of $14^{\text {th }}$ Mar 


\section{G. Grain yield.}

In general, grain yield was well simulated at $6^{\text {th }}$ March sowing for all the maize hybrids i.e. DK-6142, DK-6525 and DK-9108. Average error \%age was 2 and 3 for $6^{\text {th }}$ Feb and $14^{\text {th }}$ Mar respel2ctively. In case of $14^{\text {th }}$ Mar sowing there was higher error \%age between simulated and observed yield. These evaluation results showed the model efficiency to simulate crop yield in case of both sowing date was good. Simulated yield in both sowing dates and almost by all hybrids was higher as compared to observed yield.

[18] Kponger (2007) and [19] Liu et al. (2012)explained the similar results. Their model performed well in predicting grain yield with an average $\mathrm{R}^{2}$ of 0.85 and with forecast deviations ranging from $-2.4 \%$ to $23.0 \%$.

\section{H. Biomass}

CERES-Maize model was able to simulate time course crop biomass in good agreement with observed biomass during the evaluation with data collected from $6^{\text {th }}$ Feb and $14^{\text {th }}$ Mar sowing for all hybrids (table 4.20). Average error

$\%$ for $6^{\text {th }} \mathrm{Feb}$ and $14^{\text {th }}$ Mar sowing were -2 and $-4 \%$ respectively. At $6^{\text {th }}$ March sowing date in maize hybrids H2 (DK-6525) and H3 (DK9108) simulated biomass was higher than the observed biomass. In maize hybrids H1 (DK6142) simulated biomass was lower than observed biomass. At $14^{\text {th }}$ Mar sowing the simulated biomass yield was lower than observed biomass in all hybrids. [18] Kponger (2007) reported the good accuracy of CERESMaize for simulation of biomass at maturity with an average $\mathrm{R}^{2}$ of 0.81 . He also reported that CERES-Maize was used to explore yield prospects for a spring- sown maize crop after a winter fallow. 


\begin{tabular}{|c|c|c|c|c|c|c|c|c|c|c|c|c|}
\hline \multirow[t]{2}{*}{ Variable/ Date } & \multicolumn{3}{|l|}{ DK-6142 } & \multicolumn{3}{|l|}{ DK-6525 } & \multicolumn{3}{|l|}{ DK-9108 } & \multicolumn{3}{|l|}{ Average } \\
\hline & $\begin{array}{l}\text { Simulate } \\
\mathrm{d}\end{array}$ & Observed & Error $(\%)$ & $\begin{array}{l}\text { Simulate } \\
\mathrm{d}\end{array}$ & $\begin{array}{l}\text { Observe } \\
\mathrm{d}\end{array}$ & Error(\%) & $\begin{array}{l}\text { Simulate } \\
\mathrm{d}\end{array}$ & $\begin{array}{l}\text { Observe } \\
\mathrm{d}\end{array}$ & Error $(\%)$ & $\begin{array}{l}\text { Simulate } \\
\text { d }\end{array}$ & $\begin{array}{l}\text { Observe } \\
\mathrm{d}\end{array}$ & Error $(\%)$ \\
\hline \multicolumn{13}{|l|}{$6^{\text {th }} \mathrm{Mar}$} \\
\hline $\begin{array}{l}\text { Days to } \\
\text { flowering }\end{array}$ & 68 & 74 & -8 & 73 & 76 & -3.94 & 74 & 80 & 7.5 & 72 & 77 & -6 \\
\hline $\begin{array}{l}\text { Days to } \\
\text { maturity }\end{array}$ & 121 & 122 & -0.8 & 117 & 118 & 0.84 & 115 & 120 & 4.16 & 118 & 120 & -2 \\
\hline Maximum LAI & 4 & 3.91 & 2.3 & 3.65 & 3.7 & -1.35 & 3.7 & 3.75 & 1.33 & 4 & 4 & 0 \\
\hline Yield (kg ha-1) & 7620 & 7500 & 1.6 & 6800 & 6490 & 2.27 & 4723 & 4755 & 0.67 & 6381 & 6248 & 2 \\
\hline TDM (kg ha-1) & 14800 & 15335 & -3.4 & 13600 & 13650 & -0.03 & 13556 & 13798 & -1.75 & 13985 & 14261 & -2 \\
\hline \multicolumn{13}{|l|}{$14^{\text {th }} \mathrm{Mar}$} \\
\hline $\begin{array}{l}\text { Days to } \\
\text { flowering }\end{array}$ & 64 & 74 & -13.5 & 71 & 74 & -4.05 & 71 & 75 & 5.33 & 69 & 74 & 8 \\
\hline $\begin{array}{l}\text { Days to } \\
\text { maturity }\end{array}$ & 115 & 114 & 0.87 & 115 & 113 & 1.76 & 113 & 114 & -0.87 & 114 & 114 & 1 \\
\hline Maximum LAI & 3.75 & 3.85 & -2.59 & 3.71 & 3.47 & 6.91 & 3.62 & 3.55 & 1.97 & 4 & 4 & 0 \\
\hline Yield (kg ha-1) & 6500 & 6313 & 2.96 & 6485 & 6350 & 2.12 & 5732 & 5569 & 2.92 & 6239 & 6077 & 3 \\
\hline TDM (kg ha-1) & 13500 & 13700 & 1.45 & 12476 & 13890 & -10.17 & 12000 & 12175 & 1.43 & 12659 & 13255 & -4 \\
\hline
\end{tabular}

Table 5. Comparison of simulated and observed values of different parameters of maize hybrids sown on $6^{\text {th }}$ and $14^{\text {th }}$ March 


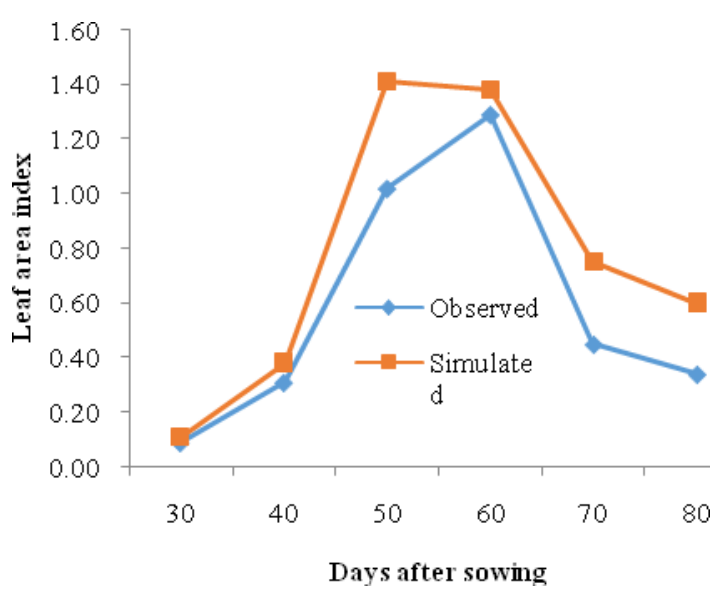

.1. Observed and simulated Leaf area index of hybrid DK- 6142 on $25^{\text {th }}$ Feb sowing.

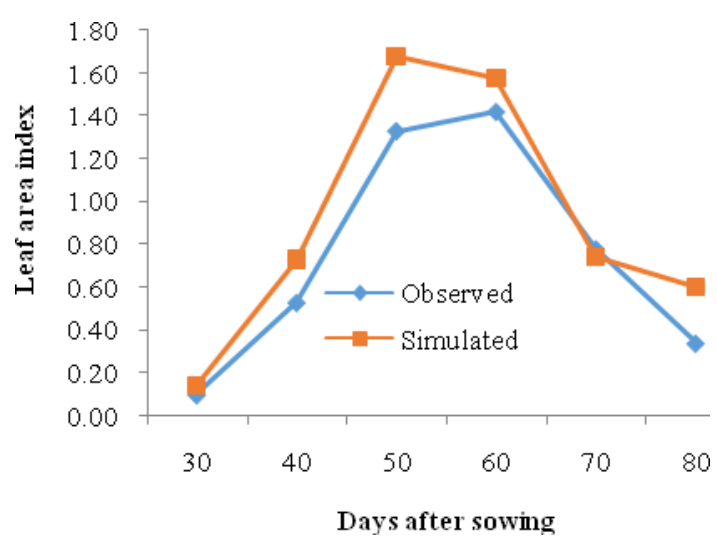

Fig.

2. Observed and simulated Leaf area index of hybrid DK-6142 on $6^{\text {th }}$ Mar sowing.

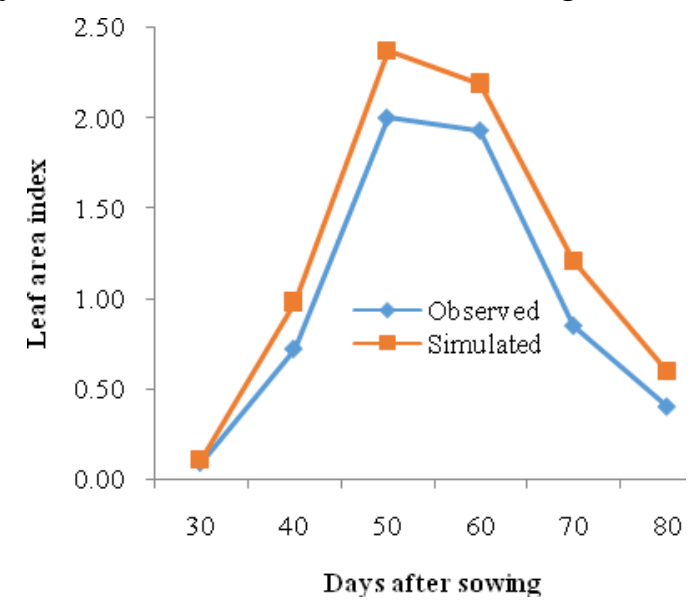

ig.3. Observed and simulated Leaf area index of hybrid DK- 6142 on $14^{\text {th }}$ Mar sowing.
Fig.4. Observed and simulated Leaf area index of hybrid DK- 6142 on $14^{\text {th }}$ Mar sowing.

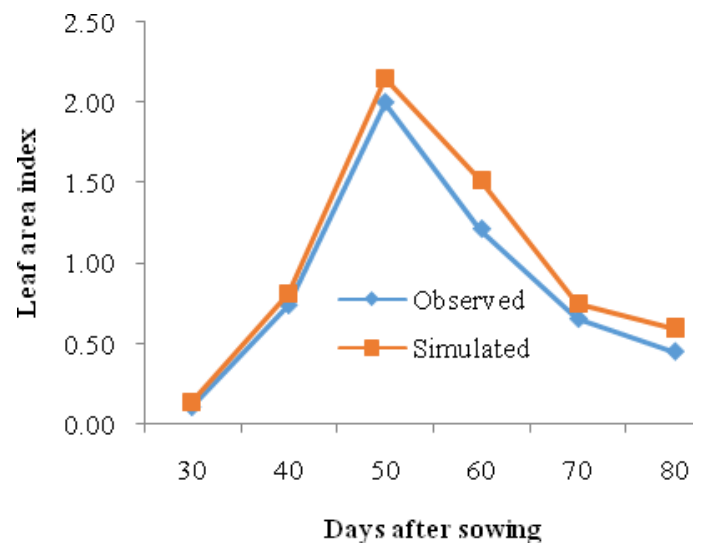

g.5. Observed and simulated Leaf area index of hybrid DK- 6525 on $6^{\text {th }}$ Mar sowing.

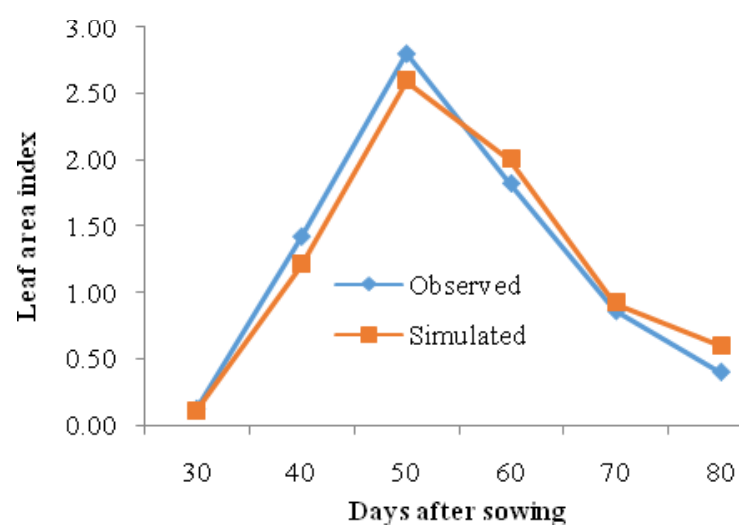

Fig. 6. Observed and simulated Leaf area index of hybrid DK- 6525 on $14^{\text {th }}$ Mar sowing.

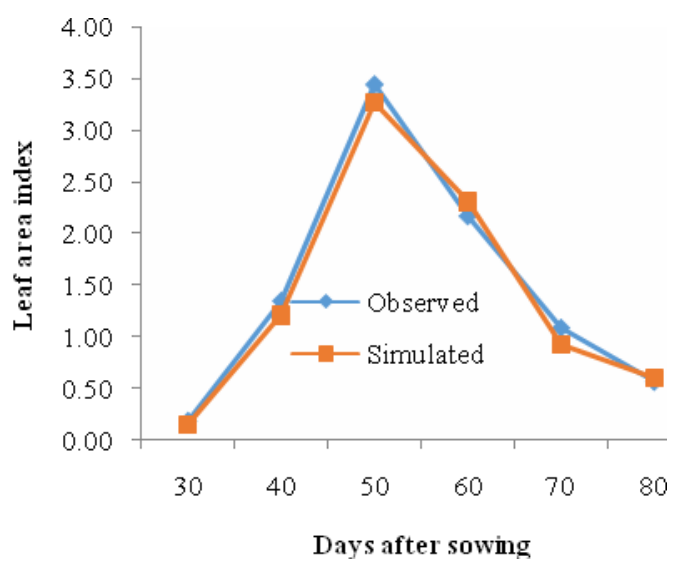

Fig.7. Observed and simulated Leaf area index of hybrid DK- 9108 on $25^{\text {th }}$ Feb sowing. 


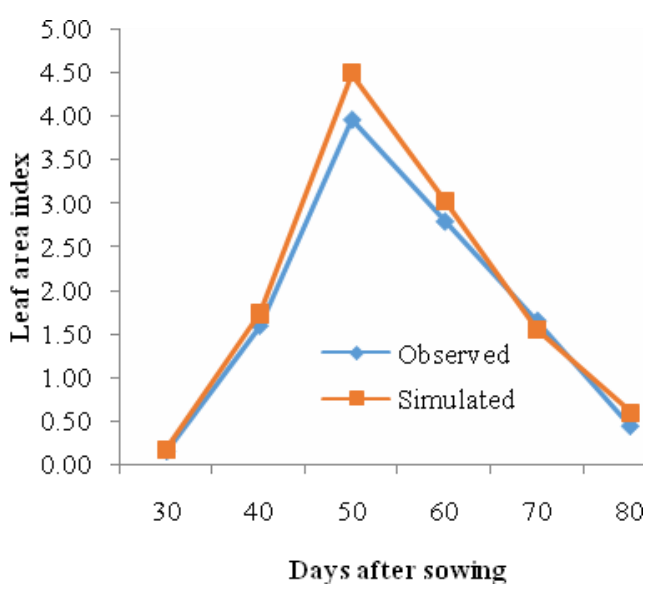

[2] Afzal, I., B. Hussain, S.M.A. Basra and H. Rehman,"Priming with moringa leaf extract reduces imbibitional chilling Injury in spring maize." Seed Sci. Technol. 40: 271-276. 2012.

Fig.

8. Observed and simulated Leaf area index of hybrid DK-9108 on $6^{\text {th }}$ Mar sowing.

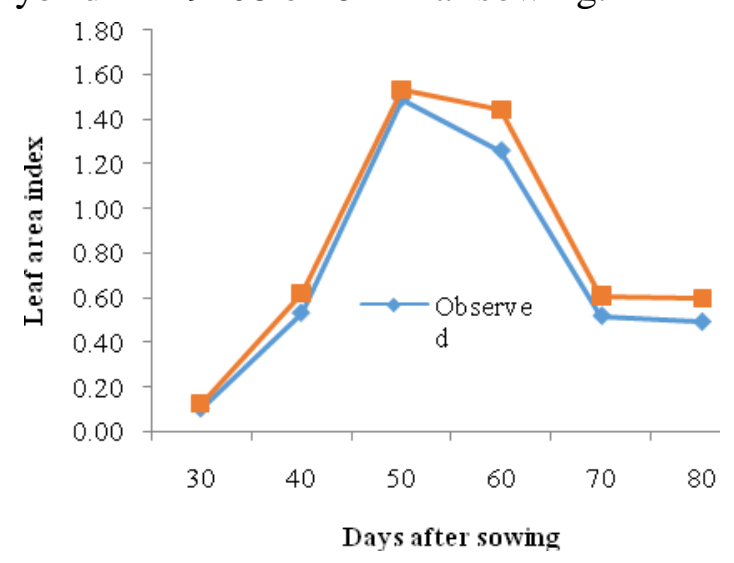

$\mathrm{Fi}$

g.9. Observed and simulated Leaf area index of hybrid DK- 9108 on $14^{\text {th }}$ Mar sowing.

\section{CONCLUSION}

The CSM-CERES-Maize model predicted phenology, growth and yield of different maize hybrids at varying sowing dates with reasonable accuracy. It may be concluded from this study that sowing date $\left(25^{\text {th }} \mathrm{Feb}\right.$ ) and Maize hybrid (DK6142 ) is best for achieving higher yield under semiarid conditions of Sargodha.

\section{REFERENCES}

[1] Harrison, U., S Jagtap, M. Lamb, "Potential effects of climate change on agricultural, water uses in southeast US," J. Amer. Water Res.Associ. 35: 1551-1561. 2011. 
[3] Forsthofer, E., P.R.F. Silva, M. Strieder, T. Minetto and $\mathrm{G}$

.Argenta,"Desempenho agronomic e economic do milhoemdifferentesniveis demanejo e eepocas de desemeadra,"PesquisaAgropecuaria Brasilia. 41: 399- 407. 2006.

[4] Sarvari, M. and Z. Futo, "Correlation between the sowing date, yield and grain moisture content of maize hybrids on the chernozem soil,'Debr. Egypt. AgricKozl. J. 1:32-41. 2000.

[5] Berzsenyi, Z. and D.Q. Lap, "Effect of sowing time and $\mathrm{N}$ Fertilization on the yield and yield stability of maize (Zea mays L.) hybrids between 1991- 2000,"Acta.Agron. Hung. 50: 309-331. 2001.

[6] Fischer, G., M. Nachtergaele and V. Velthunizen,"Global agro-ecological assessment for agriculture in the $21^{\text {st }}$ century," In proceeding of IIASA, Vienna. 2000.

[7] Hammer, G.L.,M.J. Kropff, T.R. Sinclair and J.R. Porter, "Future contributions of crop modeling from heurisistics and supporting deciscion making to understanding gentic regulation and aiding crop improvement," Eur. J. Agron. 18: 15-31. 2002.

[8] Hansen, J.W, "Realizing the potential benefits of climate prediction to agriculture; issues, approaches, challenges," Agric. Syst.74: 309-330. 2002.

[9] Stephens, W. and T. Middleton, "Why has the uptake of decision support system been so poor?," In : Matthews, R. and Stephens W. (Ed.) Crop-soil simulating models. 129-147. CAB International, Wallingford, UK. P.P. 129- 147. 2002.

[10] Keating. B.N., P.S. Carberry, G.L. Hammer, M.J. Probertson, D. Holzworth, N.J. Huth, J.N.G [17] Lizaso, J.I., K.J. Boote, J.W. Jones, C.H. porter, L. Echarte, M.E. Westgate and G. Sonohat, CSM. IXIM: A New Maize Simulation
Hargreaves, M.Meikine, Z. Hochman, G. Meclean, K. Verburg, V. Snow, J.P. Dimes, M, Sliburn, E. Wang, S. Brown,

K.L. Bristow. S. Asseng, S. Chpman, R.L. Mccwn, D.M. An overview of APSIM, a model designed for farming systems simulation. European Journal of Agronomy. 18: 267-288. 2003.

[11] Keating, B.A. and R.L, McCown, “Advances in farming system analysis and intervention," Agric. Sys. 70: 555-579. 2001.

[12] $\mathrm{Wu}$, D.R., Q. Yu, C.H $\mathrm{Lu}$ and $\mathrm{H}$. Hensdijk, "Quantifying production potential of winter wheat in the North China Plain," Eur. J. GRON. 24: 226- 235. 2006.

[13] Wang, E., Chen and Q. Yu, "Modeling the response of wheat and maize productivity to climate variability and irrigation in the North Chine Plain," Agron.J 92: 88-91.2009.

[14] Hoogenboom, G., C.H, Porter, P,W. Wilkenes, K.J. Boote, L.A. Hunt and

J.w. Jones, “The deciscion support system for agro technology Transfer (DSSAT); past, current and future development. In programmed and summaries, Biological, Systems Simulation Conf., 40th, 13-15 Apr, 2010. USDA-ARS- ARID- Land Agric. 50-51. 2010.

[15] Verma, N.K., B.K. Pandy, U.P Singh and M.D. Lodhi, "Effects of sowing dates in relation to to integrated nitrogen management on growth, yield and quality of rabi maize," J. Anim\& Plant Sci. 22: 324-329. 2012.

[16] Chen, C., E. Wang and Y. Qiang,"Modeling the effects of climate variability and water management on crop water productivity and water balance in the North china Plain,” Agric. Water Manag. 97: 11751184. 2010. 
Model for DSSSAT version 4.5. Agron. J. 103:

766-779. 2011

[18] Kpongor, D.S, “Spatially explicit modeling of sorghum (Sorghum bicolor L.)(Moench) production on complex terrain of a semi-arid region in Ghana using APSIM," Ecology and development Series No. 51.Ph.D. Dissertation. PP: 78- 104. 2007.

[19] Liu, Y., S. Yang L. Shiqing and F. Chen. Application of the hybrid- maize model for limits to maize productivity analysis in semiarid environment. Sci. Agric. 69: 300-307. 2012. 
